\title{
ДИСПЕТЧЕРИЗАЦІЯ МАТЕРІАЛЬНИХ ПОТОКІВ З ДИНАМІЧНОЮ КОРЕКЦІЕЮ ШЛЯХОМ ОБЕРНЕНОГО РОЗПОВСЮДЖЕННЯ ПРІОРИТЕТІВ
}

\author{
Анотація: у роботі розглядається метод організації оперативно- \\ диспетчерського управління матеріальними потоками 3 динамічною коре- \\ кцією, який будується на основі алгоритму Дейкстри та методик створення \\ неперервно плануючих агентів. \\ Ключові слова: інтелектуальний агент, матеріальний потік, логістична си- \\ стема.
}

\section{Вступ}

Організація матеріальних потоків і управління ними на підприємстві нерозривно пов'язані між собою і утворюють систему. Так, переміщення матеріалів в процесі виконання отриманих замовлень неможливе без управління, яке здійснюеться шляхом розподілу матеріальних ресурсів, планування господарських зв'язків і тому подібне, і в той же час вимагає певної організації: забезпечення ритмічного виконання постачань, вибору оптимальної системи транспортування матеріалів та ін.

В процесі організації досягається об'єднання елементарних потоків і створюються умови для ефективного фрункціонування виробничої логістичної системи. Управління матеріальними потоками забезпечуе постійний контроль за ходом виконання виробничих замовлень і чинить необхідну дію на логістичну систему з тим, щоб утримувати їі параметри в заданих межах для досягнення поставлених перед підприемством цілей [1].

\section{Пріоритети на виробництві}

Диспетчеризація матеріальних потоків на виробництві як підзадача тактичного рівня управління здійснюеться в рамках виробничої системи або за стратегією транспортного обслуговування, або за синхронною моделлю (остання застосовуеться виключно на рівні гнучких автоматизованих ліній при можливих незначних відхиленнях в роботі системи).

В процесі диспетчеризації матеріальних потоків вирішуються три типи конфліктів, що поділяються на конфлікти за заявками, за устаткуванням, та операціями. Пріоритети за кожним типом конфліктів встановлюються таким чином, щоб досягнути запланованих обсягів випуску продукції при виникненні відхилення від

(c) A.M. Дзінько, 2014 
календарного плану. У випадку великої кількості непередбачуваних ситуацій, оперативне управління будується на стратегії транспортного обслуговування, що базується на послідовному розв'язанні конфліктів на транспортне обладнання [1].

\section{Постановка задачі}

В цій роботі пропонується розробити метод диспетчеризації матеріальних потоків, який би враховував не тільки особливості виробництва, а й працював би для більш загальних і охоплюючих структур як територіально-виробничий комплекс, що включає в себе такі структури як склади та задачі доставки засобів та продуктів виробництва між виробництвом, споживачами та проміжними точками.

Існуючі методи диспетчеризації матеріальних потоків зазвичай розробляються нарізно відповідно для виробництва та задач логістики, хоча в загальному випадку матеріальні потоки і на виробництві, і в задачах логістики мають одну і ту ж фізичну суть.

Ще одним недоліком існуючих методів є те, що задачі диспетчеризації при виникненні непередбачуваних подій в системі базуються на вирішенні так званих конфліктів заявок чи конфліктів обладнання в момент виникнення таких конфліктів, а не в самий момент виникнення непередбачуваної ситуації (наприклад, поломки обладнання, виходу з ладу транспортних модулів).

\section{Порядок обчислення пріоритетів для методу оберненого розповсюдження}

В запропонованому методі пропонується застосування єдиного пріоритету на кожен вхідних матеріальний потік гнучкого виробничого модуля.

Розглянемо кожен виробничий ресурс як окремий інтелектуальний агент, що веде неперервне планування своєї діяльності, а саме - формування вимог до отримання заготовок (вхідні матеріальні потоки). Уведемо наступні цілі такого інтелектуального агента, що планує і веде діяльність в реальному світі [3]:

- агент прагне до якомога вищого завантаження:

$$
\max \left(L=T_{\text {роб }} / T_{\text {заг }}\right) ;
$$

- агент прагне до мінімізації черги заявок:

$$
\min \left(Q=Q_{\text {накоп }} / Q_{\text {заг }}\right) \text {; }
$$

- агент прагне до отримання деталей, детале-операції для яких мають найвищий пріоритет.

Розраховуватимемо пріоритети з міркувань прямого підрахунку [2]. Візьмемо максимальне значення пріоритету “загальної вимоги на заявки" агента $P=[0 \ldots 1]$ на всі вхідні, доступні йому 
$\overline{\text { матеріальні потоки, за одиницю. Тоді } P=\sum_{i=1}^{n} p_{i} \text {, де } p_{i}-\text { пріоритет }}$ кожного окремого вхідного потоку з $n$ матеріальних потоків.

Візьмемо також до уваги черги заявок. У випадку наявності вхідних накопичувачів заготовок виконаємо корекцію пріоритету, щоб врахувати наповненість накопичувача (для мінімізації черги заявок). Тоді $P=\sum_{i=1}^{n} p o_{i} \cdot q_{i}$, де $q_{i}=1-Q_{\text {нако }} / Q_{\text {заг }}$, а $p o_{i}-$ пріоритет, що обчислюеться виключно з урахуванням мінімізації відхилень від календарного плану. 3 наведених фрормул бачимо наступну нерівність $-0 \leqslant(P, Q) \leqslant 1$, причому, у випадку максимального заповнення накопичувача, $Q=0=P=0$. У частковому випадку відсутності накопичувача $q_{i}$ може приймати значення виключно з множини $\{0,1\}$.

Для обчислення ро $_{i}$ потрібно враховувати пріоритет операцій (третій тип конфліктів), що формується на базі відхилення від початкового плану випуску продукції. Скористаємось для цього методом критичного шляху [3]. За допомогою алгоритму $\mathrm{A}^{*}$, скориставшись зваженим графом матеріальних потоків, де значеннями ребер служитимуть пріоритети $p_{i}$, обчислимо критичний шлях для кожної номенклатурної одиниці продукції (рис. 1).

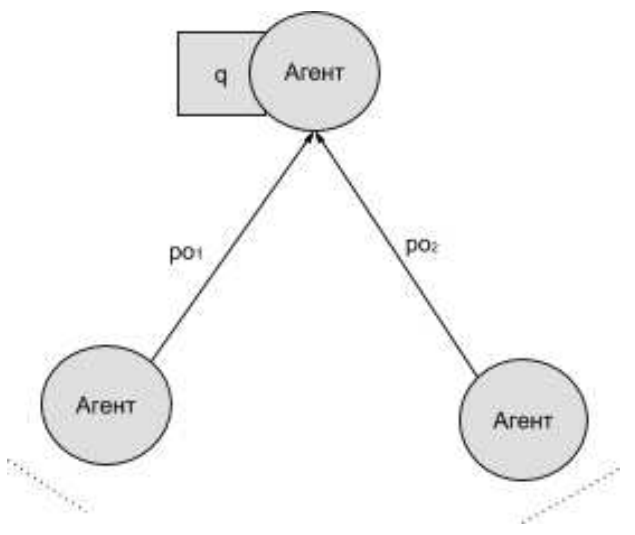

Рис. 1 - Інтелектуальні агенти та середовище

Критичний шлях $t_{\kappa p i}$, що має максимальну сумарну тривалість, візьмемо за час випуску кожної номенклатурної одиниці продукції,. Знайдемо кількість продукції, що виготовиться за певний період часу $t_{n i}$, за формулою $n_{i}=t_{n i} / t_{\kappa p i}$. Тоді відхилення від плану становитиме $\delta_{i}=n_{n i}-n_{i}$, а сумарне відхилення $-\Delta=\sum_{i=1}^{n} \delta_{i}$. Таким чином, необхідні коефіцієнти ро 
порції кожного відхилення в сумарному відхиленні $\Delta$, попередньо нормалізувавши значення сумарного відхилення до одиниці.

Шоб отримати цілісну математичну модель на початку запуску виробничої системи, для кожного агента розставимо пріоритети вхідних потоків рівномірно, тобто $P=\sum_{i=1}^{n} 1 / n=1$.

\section{Висновок}

Розроблений метод при перевірці на імітаційних моделях дає швидшу адаптацію системи до неочікуваних подій, ніж метод послідовного розв'язання конфліктів заявок. Також варто зазначити, що сам метод не оперує таким поняттям як конфлікт заявок, а виходить виключно з оцінки пріоритетів матеріальних потоків.

Результати, досягнуті в результаті тестування використання методу диспетчерування матеріальних потоків з динамічною корекцією шляхом оберненого розповсюдження пріоритетів, вказують на перспективність використання та розвитку обраного напрямку досліджень. Тестування відбувалось з застосуванням імітаційної моделі на прикладах простих систем, що не враховують транспортну мережу підприємства в загальному, а також можливу наявність регуляторів руху транспортних модулів.

Метод має потенціал до удосконалення, наприклад, шляхом прогнозування відхилень на базі історії динаміки зміни пріоритетів, а також введення механізмів співпраці між агентами [3].

Серед недоліків варто зазначити неврахування транспортних розв'язок (світлофорів та семафорів), що присутні в складних виробничих системах, а також вихідних накопичувачів обробляючих ресурсів.

\section{Література}

1. Ялипольський Л.С. Гнучкі комп'ютеризовані системи: проектування, моделювання і управління: Підручник / Л.С. Ямпольський, П.П. Мельничук, Б.Б. Самотокін, М.М. Поліщук, М.М. Ткач, К.Б. Остапченко, О.І. Лісовиченко. - Житомир: ЖДТУ, 2005. $680 \mathrm{c}$.

2. Новичихин P.B. Моделирование производственных систем обработки деталей в машино- и приборостроении: монография / P.В. Новичихин, Е.Р. Новичихина. - Минск: БНТУ, 2010. - 309 с.

3. С. Рассел, П. Норвиг. Искусственный интеллект: современный подход, 2-е изд.. : Пер. с англ. - М.: Издательский дом “Вильямс", 2006. - 1408 с. : ил. - Парал. тит. англ.

Отримано 18.03.2014 p. 